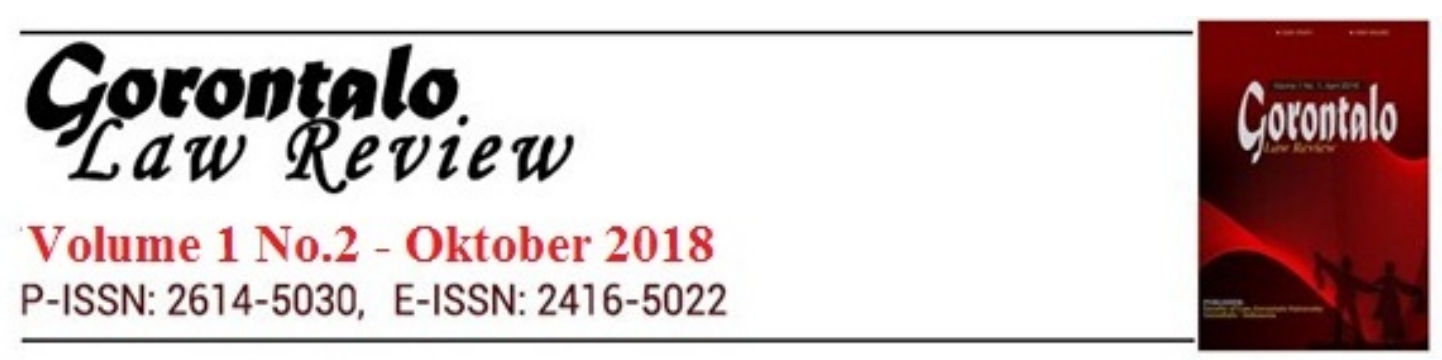

\title{
DESENTRALISASI BADAN PEMBERDAYAAN MASYARAKAT DAN PEMERINTAH DESA DALAM MENDUKUNG TATA PEMERINTAHAN DAERAH KABUPATEN GORONTALO
}

\author{
Nurwita Ismail \\ Ilmu Hukum, Fakultas Hukum Universitas Gorontalo \\ Email: Nhurwita.ismail@gmail.com
}

\begin{abstract}
Abstrak
Keberdayaan Badan Pemberdayaan Masyarakat dan pemerintahan desa merupakan suatu keniscayaan untuk mewujudkan masyarakat dan pemerintah desa yang mandiri. Dalam upaya pencapaian kondisi mandiri tersebut sangat dipengaruhi oleh tingkat keberhasilan program kegiatan pemberdayaan. Berbagai permasalahan dapat muncul dalam setiap pelaksanaan program kegiatan yang berdampak terhadap kualitas keberhasilan program. Tulisan ini bertujuan Untuk mengetahui dan menganalisis Bagaimanakah desentralisasi Badan Pemberdayaan Masyarakat Dan Pemerintahan Desa dalam mendukung tata Pemerintahan Daerah di Kabupaten Gorontalo serta faktor yang mempengaruhi dalam penerapannya. Permasalahan dilakukan dengan menggunakan metode dianalisis secara kualitatif, kemudian disajikan secara deskriptif. Pemerintahan Desa memiliki peran penting dalam mendukung pembangunan nasional olehnya diharapkan desa mampu menetapkan suatu peraturan secara baik dan benar-benar menyentuh kepentingan masyarkat olenya pemerintah daerah dalam hal ini Badan Pemberdayaan Masyarakat dan Pemerintahan Desa (BPM-PEMDes) diharapkan agar terus melaksanakan perannya dalam mengawal pemerintahan yang ada didesa.
\end{abstract}

\section{Kata kunci : BPM-PEMdes, Pemerintah Desa}

\begin{abstract}
Abstrac
Empowerment of Community Empowerment Agencies and village government is a necessity to create independent village communities and governments. In an effort to achieve these independent conditions it is strongly influenced by the level of success of the empowerment activities program. Various problems can arise in each program implementation activities that have an impact on the quality of the program's success. This paper aims to find out and analyze how the decentralization of the Community Empowerment Agency and Village Government in supporting Regional Governance in Gorontalo Regency and the factors that influence its implementation. The problem is done using a method analyzed qualitatively, then presented descriptively. The Village Government has an important role in supporting national development. It is hoped that the
\end{abstract}


village will be able to establish a regulation well and really touch the interests of the local community in this case the Community Empowerment and Village Governance Agency (BPM-PEMDes) is expected to continue to carry out its role in guarding the government in the village.

Keywords: BPM-PEMdes, Village Government

\section{PENDAhuluan}

Reformasi dan otonomi daerah sebenarnya adalah harapan baru bagi pemerintah dan masyarakat desa untuk membangun desanya sesuai kebutuhan dan aspirasi masyarakat. Bagi sebagian besar aparat pemerintah desa, otonomi adalah suatu peluang baru yang dapat membuka ruang kreativitas bagi aparatur desa dalam mengelola desa, misalnya semua hal yang akan dilakukan oleh pemerintah desa harus melalui rute persetujuan kecamatan, untuk sekarang hal itu tidak berlaku lagi. Hal itu jelas membuat pemerintah desa semakin leluasa dalam menentukan program pembangunan yang akan dilaksanakan, dan dapat disesuaikan dengan kebutuhan masyarakat desa.

Seiring dengan bergulirnya Reformasi dan Demokratisasi, di Daerah-daerah yang bersifat Otomom akan diadakan Badan Perwakilan Daerah,di Daerahpun pemerintahan akan bersendi atas permusyawaratan. Dalam penyelenggaraan Pemerintahan Daerah dan Desapun sedikit banyak mengalami perubahan. Salah satunya perubahan di Daerah adalah dibentuknya Badan Pemberdayaan Masyarakat dan Pemerintahan Desa dalam mendukung sistem pemerintahan yang lebih efektif dan efisien dalam suatu daerah. (Roy Marthen Moonti,2018)

Era otonomi daerah dalam dinamika demokrasi yang terjadi di Indonesia sekarang ini, menuntut adanya regulasi daerah untuk menjembatani antara kepentingan masyarakat dengan percepatan pembangunan yang ada di daerah. Maka menarik apabila menyoroti regulasi di level satuan wilayah unik yang ada di Indonesia yaitu Desa. (Bagus Oktafian Abrianto, 2011) Hukum harus memberikan jaminan kepastian akan hak dan kewajiban seseorang dan hukum menjamin kepastian tidak adanya kesewenang-wenangan dalam masyarakat.

Lahirnya Peraturan Pemerintah Nomor 18 Tahun 2016 Tentang Organisasi Perangkat daerah,menunjukan adanya dinamika baru dalam pembentukan organisasi perangkat daerah yang benar-benar sesuai dengan kebutuhan dan kemampuan daerah yang mampu melaksanakan tugas pokok dan fungsinya dengan efisien, efektif, dan rasional, senantiasa mengedepankan koordinasi dan simplikasi serta komunikasi diantara lembaga sesama perangkat organisasi perangkat daerah yang berbentuk tidak terlalu besar dan tidak terlampau lebar pembandingannya. Selain itu dengan semangat pembaharuan fungsifungsi pemerintah dalam rangka mendukung terwujudnya tata pemerintahan yang baik (Good Govermence) akan tercipta organisasi perangkat daerah yang lebih afisien dengan memberi ruang partisipasi masyarakat yang lebih besar dalam penyelenggaraan pembangunan di daerah. 
Sebagai wujud dari implementasi penyelenggaraan urusan dibidang pemberdayaan masyarakat dan pemerintah desa yang sejalan pula dengan realitas kebutuhan pemerintah, pembangunan dan pelayanan masyarakat maka perlu mambentuk organisasi perangkat yang bekenaan dengan urusan dimaksud dan mengacu pada besaran organisasi dan perumpunan perangkat daerah sebagaimana yang diatur dalam Peraturan Pemerintah Nomor 18 Tahun 2016 Pasal 19 ayat (1) yang menyatakan bahwa Pembentukan, Kedudukan, Tugas, Susunan Organisasi, dan Tata Kerja kelurahan diatur sesuai dengan peraturan Perundang-undangan. Dan Pasal (22) Peraturan Pemerintah Nomor 41 Tahun 2007 tentang Organisasi Perangkat Daerah tentang Perumpunan Urasan Pemerintahan.

Pembentukan Badan Pemberdayaan Masyarakat Dan Pemerintahan Desa pada umumnya dan untuk Kabupaten Gorontalo pada khususnya adalah merupakan Unsur Pendukung tugas kepala Daerah yang mempunyai tugas melaksanakan penyusunan dan pelaksanaan kebijakana daerah yang bersifat spesifik.

Untuk menyelenggarakan tugasnya sebagaimana dimaksud dalam pasal (5) PERDA Nomor 19 Tahun 2007 Tentang Pembentukan Organisasi dan Tata Kerja Badan Pemberdayaan Masyarakat dan Pemerintah Desa Kabupaten Gorontalo menerangkan bahwa fungsi BPM-Pemdes sebagai berikut:

a. Perumusan kebijakan teknis sesuai dengan lingkup tugas.

b. Pemberian dukungan atas penyelenggaraan pemerintahan daerah sesuai dengan lingkup tugasnya;

c. Pembinaan dan pelaksanaan tugas sesuai dengan lingkup tugasnya;

d. Pelaksanaan tugas lain yang diberikan oleh Kepala Daerah sesuai dengan tugas dan fungsinya.

Badan Pemberdayaan Masyarakat dan Pemerintahan Desa ini dibentuk guna mengharapkan organisasi ini mampu mengutamakan aspek koordinasi, integrasi, sinkronisasi dan simplikasi serta komunikiasi kelembagaan antara pemerintah pusat dan daerah guna dapat terwujudnya tata pemerintahan yang baik ( Good Govermence).perlunya dorongan untuk memberdayakan masyarakat, menumbuhkan prakarsa dan kreativitas serta peran serta masyarakat dalam perencanaan dan pelaksanaan program. Dengan demikian melalui proses pemberdayaan masyarakat diharapkan hasil-hasil pembangunan dapat dimanfaatkan, dipelihara dan dikembangkan oleh masyarakat.

Mengacu pada pokok-pokok pikiran diatas, penulis terertarik tentang “ Desentralisasi Badan Pemberdayaan Masyarakat dan Pemerintah Desa Dalam Mendukung Tata Pemerintahan Daerah Kabupaten Gorontalo.Berdasarkan pokok bahasan diatas, penulis lebih menekankan pada pokok permasalahan diataranya ; bagaimana peran BPM-Des dalam mendudukng Tata pemerintahan Daerah Kabupaten Gorontalo? Serta Faktor yang mempengaruhi dalam penerapanya?.

Dalam menemukan jawaban tentang rumusan masalah, penulis melakukan penelitian pada Badan Pemberdayaan masyarakat dan Pemerintah Desa (BPM-PEMDes) Kabupaten Gorontalo dengan menggunakan jenis penelitian Normatif Empiris yaitu penelitian secara langsung dilapangan mengenai perilaku masyarakat dan diperkuat oleh literatur pendukung data. Penelitian yang secara langsung mengunakan data primer yaitu penelitian tentang data yang diperoleh secara langsung 
dilapangan baik dari responden yang ada kaitannya dengan objek penelitian.

Data yang diperoleh melalui penelitian dianalisis secara kualitatif, kemudian disajikan secara deskriptif yaitu menggambarkan, menguraikan dan menjelaskan sesuai dengan permasalahan yang erat kaitannya dengan penelitian ini. Penggunaan teknik analisis kualitatif mencakup semua data yang telah diperoleh melalui instrumen yang digunakan dalam penelitian.

\section{PEMBAHASAN}

a. Peran BPM-PEMDes dalam mendudukng Tata pemerintahan Daerah Kabupaten Gorontalo

Dalam mendukung sistem pemerintahan di daerah khususnya kabupaten gorontalo, sesuai dengan Peraturan Daerah Nomor 19 Tahun 2007 tentang Organisasi dan Tata Kerja BPM-PEMDES Kabupaten Gorontalo. Sesuai dengan Visinya "Masyarakat dan aparatur pemerintahan desa yang mandiri" maka BPM-Pemdes memiliki tujuan dalam mendukung tata pemerintahan Daerah Kabupaten Gorontalo diantaranya :

1. Meningkatkan Kinerja Pemerintahan Desa dalam Pengelolaan Keuangan Desa

2. Meningkatkan Peran serta Masyarakat dalam Pembangunan Desa.

3. Meningkatkan Taraf Hidup Masyarakat dan Pengentasan kemiskinan.

4. Meningkatkan Sumber Daya Aparatur pemerintahan desa.

Menurut Bapak Drs. Hikmat Nurhayat, selaku Sekretaris menyatakan bahwa Perana Badan Pemberdayaan Masyarakat dan Pemerintahan Desa (BPM-Pemdes) sebagai Satuan Kerja Perangkat Daerah (SKPD) Pemerintah Kabupaten Gorontalo senantiasa mendukung capaian Visi dan Misi yang dijabarkan oleh berbagai program/kegiatan yang berkaitan dengan kebutuhan masyarakat sesuai tugas pokok dan fungsi SKPD yaitu malaksanakan kewenangan desentralisasi di bidang Pemberdayaan Masyarakat dan Pemerintahan Desa (Wawancara 02 April 2016). Olehnya perlu adanya program yang tepat sasaran sehingga capain kinerja BPM-Pemdes terarah dan dapat diukur diantaranya:
1. Meningkatnya Kinerja Pemerintahan Desa dalam PengelolaanKeuangan Desa
2. Meningkatnya Peran serta Masyarakat dalam Pembangunan Desa.
3. Meningkatnya taraf hidup Masyarakat dan PengentasanKemiskinan.
4. Meningkatnya Sumber Daya Aparatur Perintahan Desa

\section{STRATEGI DAN KEBIJAKAN}

STRATEGI

a.Peningkatan peran aktif kelompok masyarakat dalam membangun desa.

b.Peningkatan usaha-usaha masyarakatdesa.

c.Peningkatan pengetahuan dan wawasan aparatur pemerintahan desa

d.Peningkatan kualitas kelembagaan masyarakat dan pemerintahan desa.

1. KEBIJAKAN

a.Meningkatkan upaya-upaya pembinaan kelompok masyarakat yang ada di pedesaan. 
b. Mengefektifkan pemanfaatan fasilitasi permodalan yang telah diberikan kepada kelompok-kelompok usaha masyarakat pedesaan.

c. Memberikan akses yang luas bagi aparatur pemerintahan desa untuk mendapatkan pengetahuan dan wawasan melalui pelatihan.

d. Meningkatkan upaya-upaya pembinaan kelembagaan masyarakat dan pemerintahan desa agar dapat menjangkau lebih luas dan menyeluruh kepada anggota lembaga tersebut.

Menurut Undang-undang nomor 23 tahun 2014 Tentang Pemerintahan Daerah, Desentralisasi dimaknai sebagai penyerahan wewenang pemerintah oleh pemerintah kepada daerah otonom untuk mengatur dan mengurus urusan pemerintahan dalam sistem Negara Kesatuan Republik Indonesia.

Desentralisasi atau pendesentralisasian governance merujuk pada suatu upaya restrukturisasi atau reorganisasi dari kewenangan yang yang menciptakan tanggung jawab bersama diantara lembaga-lembaga di dalam governance baik di tingkat pusat, regional maupun lokal sesuai dengan prinsip saling menunjang yang diharapkan pada akhirnya adalah suatu kualitas dan efektifitas keseluruhan dari sistem governance tersebut termasuk peningkatan kewenangan dan kemampuan dari governance di tingkat lokal (UNDP, 1997).

Desentralisasi bukan sekedar memindahkan sistem politik dan ekonomi yang lama dari pusat ke daerah, tetapi pemindahan tersebut harus pula disertai oleh perubahan kultural menuju arah yang lebih demokratis dan beradab. Melalui desentralisasi diharapkan akan meningkatkan peluang masyarakat untuk berpartisipasi dalam proses pengambilan kebijakan yang terkait dengan masalah sosial, politik, ekonomi. Hal ini sangatlah dimungkinkan karena karena lokus pengambilan keputusan menjadi lebih dekat dengan masyarakat. Melalui proses ini maka desentralisasi diharapkan akan mampu meningkatkan penegakan hukum; meningkatkan efisiensi dan efektifitas pemerintah dan sekaligus meningkatkan daya tanggap, transparansi dan akuntabilitas pemerintah daerah.

Dengan sistem Sentralisasi maka keberlanjutan pemerintahan ke bawah tidak hanya berperan sebagai perpanjangan tangan atau jembatan komunikasi antara daerah dengan pusat, tetapi desa juga mempunyai kewenangan untuk melakukan tata kelola bagi daerahnya sendiri.(Khoiriza, 2016). Dalam mendukung sistem Pemerintahan Daerah khususnya Daerah Kabupaten Gorontalo, maka BPM-Pemdes mempunyai Program-program yang nantinya akan dicapai dalam mewujudkan suatu sistem pemerintahan yang baik (good govermance) diantaranya sebagai berikut :

1. Program pelayanan administrasi perkantoran

Program ini berkaitan dengan kegiatan-kegiatan yang terbaik dengan operasional kantor

2. Program peningkatan disiplin aparatur

Program ini terkait dengan pengadaan perlengkapan aparatur untuk meningkatkan disiplin seperti pakaian dinas pegawai.

3. Program peningkatan keberdayaan masyarakat pedesaan Program ini berkaitan dengan peningkatan kualitas Sumber Daya Manusia (SDM) aparatur Pemerintah serta pengurus Lembaga Masyarakat Pedesaan melalui Pelatihan dan Bimtek.

4. Program pengembangan lembaga ekonomi 
Program ini terkait dengan peningkatan tarat ekonomi masyarakat melalui peningkatan infra struktur desa serta pemberian bantuan kepada masyarakat

5. Program peningkatan partisipasi masyarakat dalam membangun desa

Program ini diarahkan pada peningkatan ketertiban masyarakat dalam membangun desa sejak perencanaan,pelaksanaan dan pengawasan serta peningkatan kualitas kelompok masyarakat seperti kelompok tentang....

6. Program peningkatan kapasitas aparatur pemerintah desa

Program ini diarahkan pada peningkatan kemampuan aparatur pemerintah desa khususnya dalam pengelolaan keuangan desa(Polontalo, Studi, \& Ilmu, 2012)

\section{Strategi Badan Pemberdayaan Masyarakat dan Pemerintahan Desa (BPM-} PEMDes)

Konsep pemberdayaan masyarakat (empowerment) mengandung pengertian sebagai:

a. To give ebility or enable to, yaitu meningkatkan kemampuan masyarakat melalui berbagai kebijakan dan program-program pembangunan.

b. To give power or autority to, yaitu memberikan kekuasaan, mendelegasikan otoritas kepada masyarakat agar memiliki kemandirian dalam mengambil keputusan dalam membangun diri dan lingkungan secara mandiri.

Dengan demikian upaya pemberdayaan masyarakat berarti memampukan dan memandirikan masyarakat.Implementasi program pembangunan yang menerapkan strategi pemberdayaan masyarakat tersebut merupakan suatu konsekuensi dari pergeseran paradigma pembangunan nasional yang mengarah kepada tercapainya upaya pembangunan yang berpusat pada manusia (people centered development)(Sumodiningrat, 1997) sehingganya dengan kehadiran BMPPEMDes ini diharapkan memberikan warna baru kepada masyarakat. Perubahan paradigma pembangunan tersebut mau tak mau menuntut adanya perubahan strategi pembangunan yang top-down ke pembangunan yang bottom-up yaitu dengan memberikan kesempatan dan akses yang sama kepada masyarakat melalui kebijakan pemihakan dan pemberdayaan (demokratisasi pembangunan)(Sumodiningrat, 1997).

Secara konseptual, pembangunan desa merupakan proses dimana usaha terpadu pada masyarakat setempat yang bertujuan untuk memperbaiki kondisi sosial, ekonomi dan budaya masyarkaat. Sebagai perwujudan demokrasi di desa Keberdadaan BPM-PEMDes sangat dibutuhkan dalam sistem pemerintahan yang ada di kabupaten Gorontalo, dalam segi pengawasan, BPM-PEMDes diberikan kewenangan mengawasi roda pemerintahan yang ada didesa seperti misalnya pengawasan Dana Desa dan BUMDES. Salain itu juga instansi ini berfungsi sebagai perumus kebijakan teknis, sebagai instansi yang berfungsi sebagai pembinaan perangkat desa serta Perumusan kebijakan pengelolaan kekayaan dan sumber pendapatan keuangan desa.

b. Faktor yang mempengaruhi dalam penerapanya

Yang terjadi saat ini masih terdapat beberapa kelemahankelemahan dalam pengaturan sistem dan mekanisme atau tata cara pengangkatan Kepala Desa melalui pemilihan Kepala Desa yang 
mengakibatkan terpilihnya seorang Kepala Desa yang hanya mampu dari segi ilmu pengetahuan dan bukan dari segi kemampuan untuk melaksanakan tugas sebagai Kepala Desa. Selain itu juga money politik dalam pemilihan kepala desa banyak terjadi sehingganya yang tepilih kurang kompeten dibidangnya dan memberikan dampak buruk terhadap sistem pemerintahan di desa lebih-lebih pada penggunaan Anggarang yang kurang tepat. Atas permasalahan inilah perlu adanya BPM-Pemdes dalam meminimalisir hal-hal yang akan terjadi.

BPM-Pemdes dalam melaksanakan tugas dan fungsinya, terdapat Faktor pangukung dan penghambat dalam pelaksanaanya diantaranya (Polontalo et al., 2012):

Tabel 1

Faktor Pendukung BPM-Pemdes

\begin{tabular}{ccc}
\hline \multirow{2}{*}{ No } & \multicolumn{2}{c}{ Faktor Pendukung } \\
\cline { 2 - 3 } & \multicolumn{1}{c}{ Internal } & \multicolumn{1}{c}{ Eksternal } \\
\hline 1 & $>$ Jumlah dan Kompetensi & $>$ Adanya regulasi yang \\
& pegawai yang memadai & menunjang pelaksanaan \\
& $>$ Sarana dan Fasilitas & tugas \\
& Kantor & $>$ Pemahaman masyarakat \\
& $>$ Kebijakan dan dukungan & yang mendukung \\
& Pimpinan & terhadap pelaksanaan \\
& $>$ Dukungan anggran yang & program/Kegiatan SKPD \\
& memadai & \\
\hline \multirow{2}{S}{ Sumber Data: Kantor BPM-Pemdes Kabupaten Gorontalo }
\end{tabular}

a. Faktor Penghambat

Tabel 4

Faktor Penghambat BPM-Pemdes

\begin{tabular}{cll}
\hline \multirow{2}{*}{ No } & \multicolumn{2}{c}{ Faktor Pendukung } \\
\cline { 2 - 3 } & \multicolumn{1}{c}{ Internal } & \multicolumn{1}{c}{ Eksternal } \\
\hline 1 & $>$ Kualitas dan kompetensi & $>$ Tingginya harapan \\
& yang tidak sama yang & masyarakat terhadap \\
& memerlukan pendidikan & penyelesaian \\
& lebih lanjut & permasalahan yang \\
& $>$ Frekuensi mutasi yang & disediakan oleh petugas \\
& cukup tinggi & $>$ Kompleksnya \\
& & permasalahan \\
& & masyarakat baik di \\
& & bidang pemberdayaan \\
& & masyarakat maupun \\
& & bidang pemerintahan \\
& & Desa \\
\hline
\end{tabular}

\section{PENUTUP}

Sumber Data : Kantor BPM-Pemdes Kabupaten Gorontalo

\section{Kesimpulan}

Bahwa Badan Pemberdayaan Masyarakat dan Pemerintahan Desa (BPM-Pemdes) sebagai Satuan Kerja Perangkat Daerah (SKPD) Pemerintah Kabupaten Gorontalo senantiasa mendukung pencapaian program pemerintah kabupaten dengan mewujudkan Visi dan Misi yang dijabarkan dalam berbagai Program/Kegiatan yang berkaitan dengan kebutuhan masyarakat sesuai dengan tugas pokok dan fungsi SKPD yaitu 
melaksanakan kewenangan desentralisasi di Bidang Pemberdayaan Masyarakat dan Pemerintahan Desa. Olehnya keberadaan BPM-Pemdes di lingkungan kabupaten dirasa sangat tepat.

Badan Pemberdayaan Masyarakat dan Pemerintahan Desa (BPMPemdes) merupakan instansi yang memiliki hubungan langsung dengan pemerintah desa, olehnya diharapkan BPM-Pemdes mampu melaksanakan tugas dan funsi dengan baik dan benar sesuai dengan amanat undang-undang dan tanpa adanya tendensi terhadap KKN dan unsur politik

\section{Saran}

1. Kepada instansi terkait, diharapkan lebih meningkatkan kinerja dibidang pengawasan dan pengawalan Dana Desa sehingga kecil kemungkinan terjadi hal-hal yang menyimpang dalam aturan perundangan-undangan

2. Pemerintah desa dan BMP-Pemdes sama-sama bersinergi membangun suatu sistem yang baik guna mewujudkan sistem perekonomian yang baik dan mendukung program pemerintah daerah.

\section{DAFTAR PUSTAKA}

\section{Buku}

Eko Suroto dk, 2003, Pembaharuan Pemerintahan Desa, IRE Press. Yogyakarta.

Djoko Prakoso, 1979, Kedudukan dan Fungsi Kepala Daerah beserta Perangkat Daerah di dalam Undang-Undang Pemerintahan Daerah, Bina Aksara, Jakarta.

Didik Sukriono, Pembaharuan Hukum Pemerintahan Desa Politik Hukum Pemerintahan Desa di Indonesia. Malang: Setara Press, 2010.

Hanif Nurcholis, Pertumbuhan \& Penyelenggaraan Pemerintahan Desa. Jakarta: Penerbit Erlangga, 2011.

Khoiriza, M. (2016). Desentralisasi sebagai Upaya Pembangunan Desa secara Menyeluruh Menurut UU No. 6 Tahun 2014, 50(1). Retrieved from http: / / download.portalgaruda.org/ article.php?article $=447408 \& v a l=9474$ \&title=Desentralisasi sebagai Upaya Pembangunan Desa secara Menyeluruh Menurut UU No. 6 Tahun 2014

Polontalo, K., Studi, P., \& Ilmu, S. I. (2012). Fakultas hukum fakultas hukum universitas gorontalo 2012, 1-55.

Roy Marthen Moonti, The Problem With Appoinment Of Village Agency In Haya Haya Village, Limboto, Gorontalo. Jurnal Yuridika Jilid 33 Terbitan 3 hal. 452-467

Sumodiningrat, G. (1997). Strategi Pemberdayaan Masyarakat dalam Pelaksanaan Otonomi Daerah. Retrieved from http://www.suniscome.50webs.com/data/download/008 Strategi Pemberdayaan.pd

Zainudin Ali, 2009, Metode Penelitian Hukum, Sinar Grafika, Jakarta.

\section{Undang-Undang}

UU No. 23 Tahun 2014 Tentang Pemerintah Daerah

Peraturan Pemerintah Nomor 18 Tahun 2016 Tentang Perangkat Daerah 